\title{
Efficacy of Intra-Arterial Nimodipine Therapy in The Treatment of Vasospasm After Subarachnoid Hemorrhage
}

\author{
Subaraknoid Kanama Sonrası Gelişen Vasospasmın Tedavisinde İntra \\ Arterial Nimodipin Tedavisinin Etkinlği
}

\author{
Vedat Acik ${ }^{1}$ \\ ${ }^{1}$ Adana Şehir Eğitim ve Araştırma Hastanesi Beyin ve Sinir Cerrahisi, Adana, Türkiye
}

\begin{abstract}
Background: This study aims to investigate the efficacy of intraarterial nimodipine therapy in treating patients that presented with spontaneous subarachnoid hemorrhage and developed vasospasm following aneurysm surgery.

Material and Method: The study includes 37 patients that underwent intra-arterial nimodipine therapy for the treatment of cerebral vasospasm between October 2015 and December 2019. In patients that developed vasospasm, a catheter was selectively inserted into the internal carotid artery, 1-2 mg of nimodipine was diluted with 50 ccs of saline, and was slowly infused through the catheter.

Results: In our study, we found the success rate of intra-arterial nimodipine administration to be $78.4 \%$ (neurologic findings completely improved in 29 cases). The clinical condition did not improve in $13.5 \%$ of cases and worsened in $8.1 \% .86 .4 \%$ of our patients were discharged with good outcomes (mRS score 0-1).

Conclusion: We conclude that intra-arterial nimodipine therapy is a cost-effective, safe, and successful method for the treatment of cerebral vasospasm, a condition that directly affects morbidity and mortality after subarachnoid hemorrhage. Prospective studies are needed to determine standard doses and application times in order to establish the efficacy of intra-arterial nimodipine therapy in treating cerebral vasospasm.
\end{abstract}

Keywords: Spontaneous subarachnoid hemorrhage, vasospasm, intra-arterial nimodipine therapy
Öz

Amaç: Bu çalışmada spontan subaraknoid kanama nedeni ile yatırılıp anevrizma cerrahisi sonrası vasospasma giren ve tedavide intra arterial nimodipin verdiğimiz hastaların sonuçları üzerinden intra arterial nimodipin tedavisinin etkinliğini incelemeyi amaçladık

Gereç ve Yöntem: Çalışmaya Ekim 2015 - Aralık 2019 tarihleri arasında Kliniğimizde serebral vasospasm saptanan ve intra - arterial nimodipine tedavisi uygulanan 37 hasta çalışmaya dahil edildi. Vasospasm saptanan hastalarda internal karotid artere selektif olarak katater yerleştirlip bu kataterden 1 - 2 mg nimodipine 50 cc serum fizyolojik ile sulandırılıp yavaş infüzyonla verildi.

Bulgular: Çalışmamızda intra - arteriyal nimodipin uygulaması sonrasında tedavi başarı oranımız \%78,4 (29 olguda nörolojik muayene tamamen düzeldi) olarak saptandı. Olguların \%13,5'inde klinik düzelme olmaz iken; \%8,1'inde klinik kötüleşme saptandı. Olgularımızın \%86.4'ü iyi skorla (mRS 0, 1) taburcu edildi.

Sonuç: Sonuç olarak subaraknoid kanama sonrası morbidite ve mortaliteyi doğrudan etkileyen serebral vazospazmda intra - arteriyal nimodipin tedavisinin ucuz, güvenli ve başarılı olduğunu gösterdik. Intra - arteriyal nimodipinin tedavisinin serebral vasopazmdaki etkinliğinin net olarak ortaya konulabilmesi için standart doz ve uygulama sürelerinin prospektik çalışmalarla gösterilmesi gerekmektedir.

Anahtar Kelimeler: Spontan subaraknoid kanama, Vasospazm, İntra arterial nimodipin tedavisi

Corresponding (IIletişim): Vedat Acik, Adana Şehir Eğitim ve Araştırma Hastanesi Beyin ve Sinir Cerrahisi, Dr. Mithat Özsan Bulvarı Kışla Mah. 4522 Sok. No:1 Yuregir/ADANA, Turkey

E-mail (E-posta): vedatacik74@gmail.com

Received (Geliş Tarihi): 15.05.2020 Accepted (Kabul Tarihi): 11.06.2020 


\section{INTRODUCTION}

Cerebral vasospasm is the most major cause behind morbidity (decreased cerebral blood flow, ischemic neurological deficits, and cerebral infarction) and mortality associated with aneurysmal subarachnoid hemorrhage. ${ }^{[1]}$ Cerebral vasospasm develops within 48 hours after subarachnoid hemorrhage as a result of inflammatory response but is rarely detected with angiography within the first 3 days. ${ }^{[2]}$ It is usually determined 5 to 14 days after subarachnoid hemorrhage and begins to improve within 2 to 4 weeks. ${ }^{[3,4]}$ Because of its multifactorial etiopathogenesis, several treatment options have been proposed for the treatment of cerebral vasospasm. Despite the advanced treatment efforts, $15-20 \%$ of these cases result in clinical cerebral infarction. ${ }^{[5,6]}$

Pentoxifylline and facial nerve stimulation are more recent treatmentoptions whereas common treatmentoptionsinclude clazosentan, balloon dilatation, intra-arterial papaverine, and nimodipine [isopropyl (2-methoxy-ethyl) 1,4-dihydro2,6-dimethyl-4-(3-nitrophenyl)-3,5-pyridinedicarboxylate]. $[1,2,7-10]$ Despite all these proposed treatment options, the only conventional evidence-based treatment method is hemodynamic therapy, which involves the manipulation of blood pressure, volume, and viscosity to improve cerebral blood flow. And even this treatment method is associated with a 20 to $30 \%$ risk of complications. ${ }^{[1]]}$ In patients that have severe persistent cerebral vasospasm that does not respond to hemodynamic therapy, the last resort for the prevention of cerebral infarction seems to be endovascular treatment such as transluminal balloon angioplasty or the selective intraarterial administration of vasodilators.

Previous studies have stated that intra-arterial nimodipine therapy is a safe and effective way to treat cerebral vasospasm. ${ }^{[12]}$ In this study, we aimed to investigate the efficacy of intraarterial nimodipine therapy in treating patients that presented with spontaneous subarachnoid hemorrhage and developed vasospasm following aneurysm surgery.

\section{MATERIAL AND METHOD}

\section{Study population}

This retrospective study was conducted between January and April 2020 in the Adana City Training and Research Hospital Brain and Nerve Surgery Department. The study was carried out with the permission of Adana City Training and Research Hospital Clinical Researches Ethics Committee (Permission granted 03.06.2020, Decision No. 903). This study was prepared in accordance with the Law on Protection of Personal Data, by anonymizing patient data and in accordance with the 2013 Brazil revision of the Helsinki Declaration and guidelines for Good Clinical Practice.

Sixty-thirty eight patients with cerebral aneurysm were treated endovascularly or surgically in our clinic between October 2015 and December 2019. The patients who developed early neurological deterioration and did not have any significant indicators of pathology in blood or radiography results underwent cerebral angiography for suspected cerebral vasospasm. 37 patients that underwent intra-arterial nimodipine therapy for cerebral vasospasm were included in the study. Other patients were excluded. Patients with clinical signs of vasospasm were included in the study. Patients with radiological vasospasm and no clinical deterioration were excluded from the study. In all subarachnoid hemorrhage cases, 2 - $\mathrm{h}$ and 3 - $\mathrm{h}$ treatments were applied in the preoperative and post operative period, and despite this treatment, nimodipine treatment was given to patients with vasospasm clinic.

The patients' clinical and demographic characteristics, cerebral aneurysm localization, Glasgow Coma Scores (GCS), Fischer scores, and pre-stroke and discharge modified Rankin Scores (mRS) were recorded from patient files.

\section{Intra - arterial nimodipine application}

Intra-arterial nimodipine administration was performed in the angiography department. Patients were brought to the angiography department and underwent intra-arterial pressure monitoring. Cerebral imaging was performed using a diagnostic catheter inserted through a femoral artery sheath. In patients that developed vasospasm, a catheter was selectively inserted into the internal carotid artery, 1-2 mg of nimodipine was diluted with 50 ccs of saline, and was slowly infused through the catheter. The patients were monitored with intra-arterial blood pressure monitoring during the procedure. This procedure was continued for 5-7 days according to the improvement of the patients' neurological findings.

\section{Statistical analysis}

Data were analyzed using SPSS for Windows version 20 (IBM SPSS Inc., Chicago, IL). The normality of data distribution was evaluated by the Kolmogorov-Smirnov test. Normally distributed numerical data were expressed as mean \pm standard deviation. Categorical variables were expressed as numbers and percentages. 


\section{RESULTS}

The clinical and demographic characteristics and treatment protocols of the subjects are presented in Table 1 in detail. The study population consisted of 20 male and 17 female patients. The mean age of the subjects was $56.3 \pm 10.8$ years. The mean GCS was $13.45 \pm 0.77$. All patients were operated on within 72 hours. 4 patients underwent endovascular treatment and 33 underwent open surgery. 28 patients developed unilateral and 9 developed bilateral cerebral vasospasm (Figures 1-3).
Following intra-arterial nimodipine therapy, the neurological findings improved completely in 29 subjects (78.4\%), did not improve in 5 (13.5\%), and worsened in 3 (8.1\%). Angiographic improvement was observed in only 15 patients (40.5\%). The discharge modified Rankin Scores of the subjects were as follows: mRS 0 in twenty-one (56.8\%), mRS 1 in eleven (29.7\%), mRS 2 in three (8.1\%), and mRS 3 in two (5.4\%). $3(8.1 \%)$ patients developed superficial infection at the site of femoral artery sheath insertion, all of which improved after medical treatment.

\section{Table 1. Clinical, demographic and radiological findings of the study population}

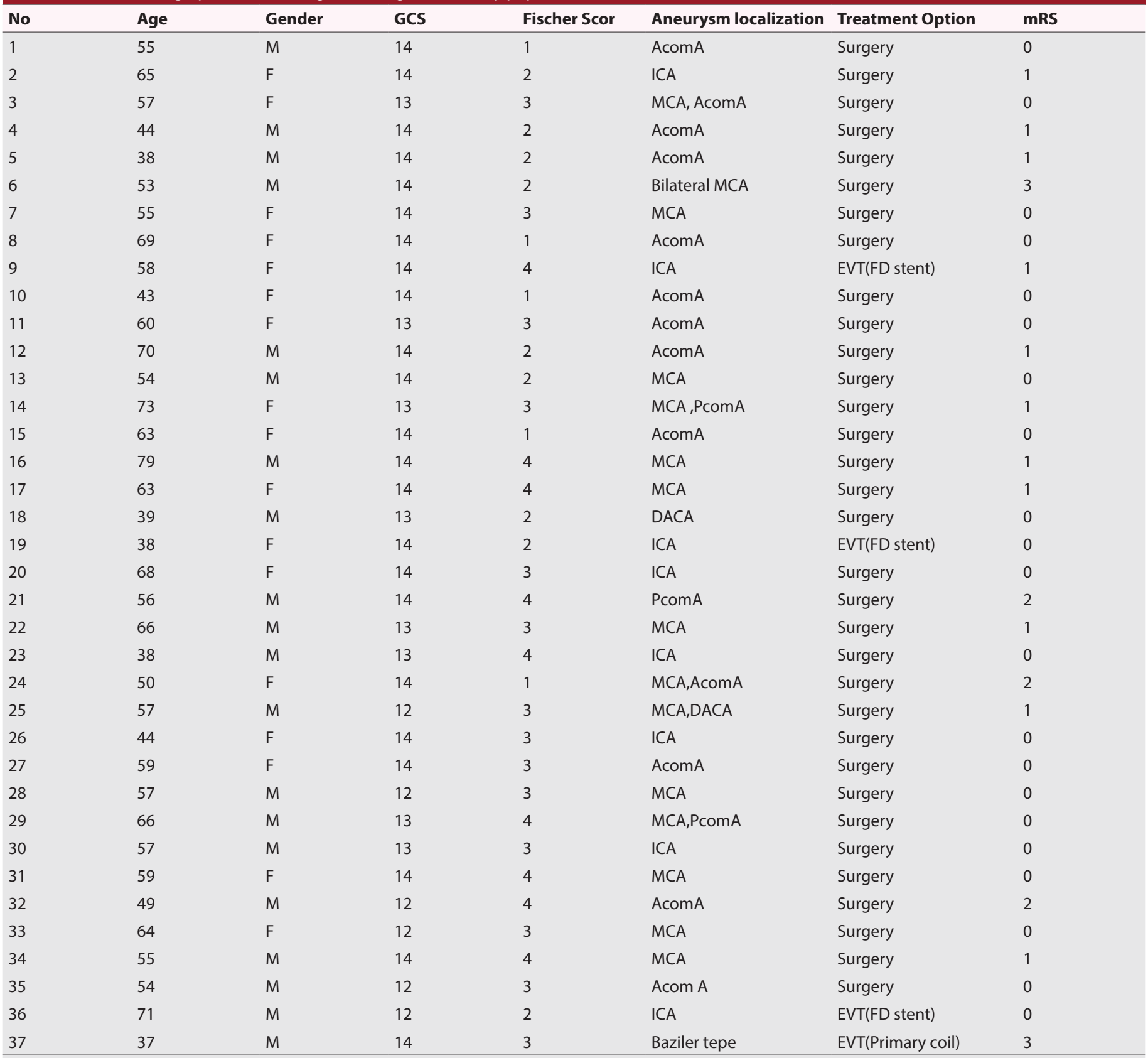

Abbreviations: GCS: Glasgow coma scale, mRS: Modified rankin score, M: Male, F: Female, AcomA: Anterior communicating artery, MCA: Middle cerebral artery, PcomA: Posterior communicating artery, ICA: Internal carotid artery, DACA: Distal anterior cerebral artery, EVT: Endovascular treatment, FD: Flow diverting 


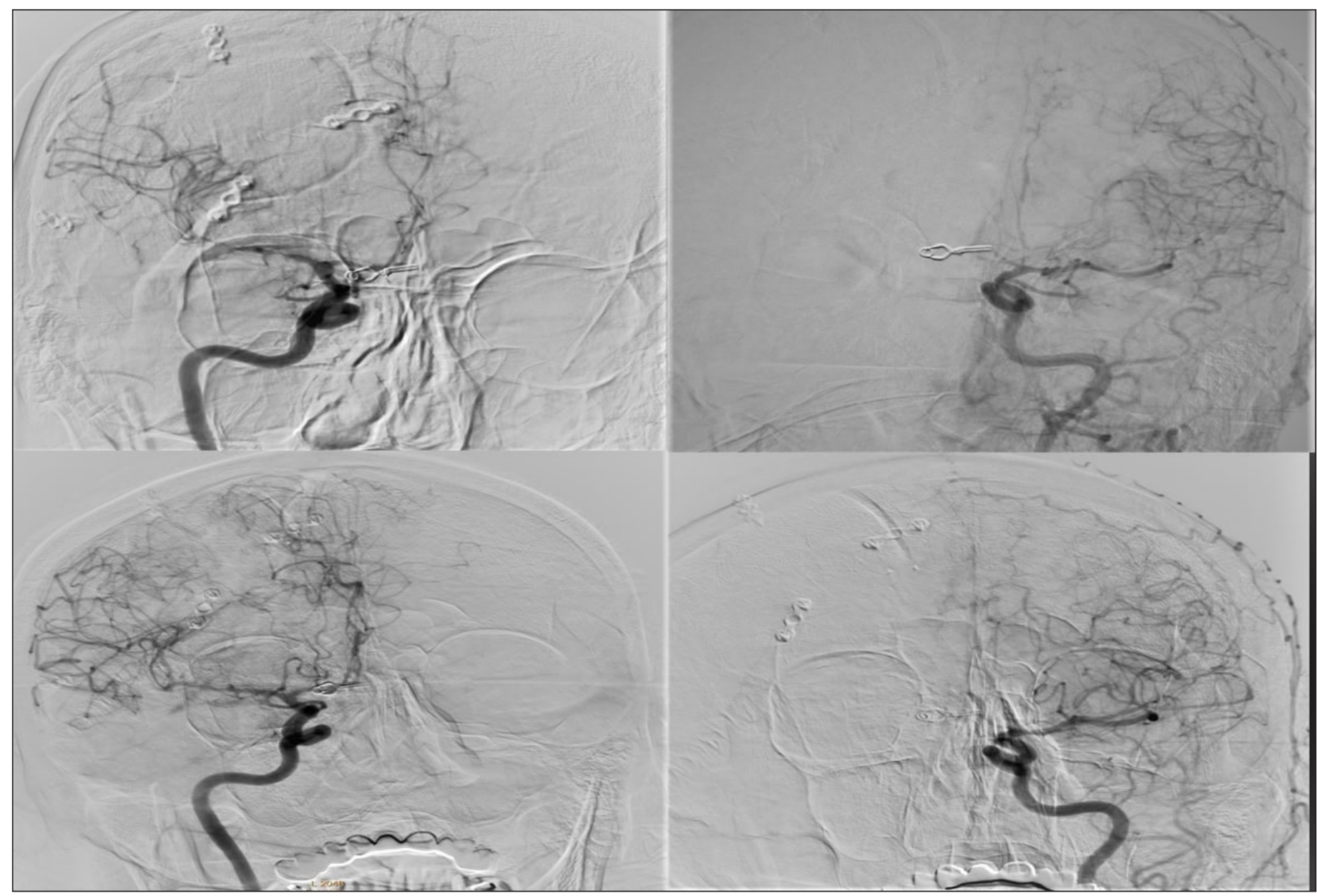

Figure 1. Patient who underwent right-sided intervention for anterior communicating artery aneurysm but developed bilateral vasospasm (top). Partial radiological improvement in the same patient after intra-arterial nimodipine therapy (bottom).

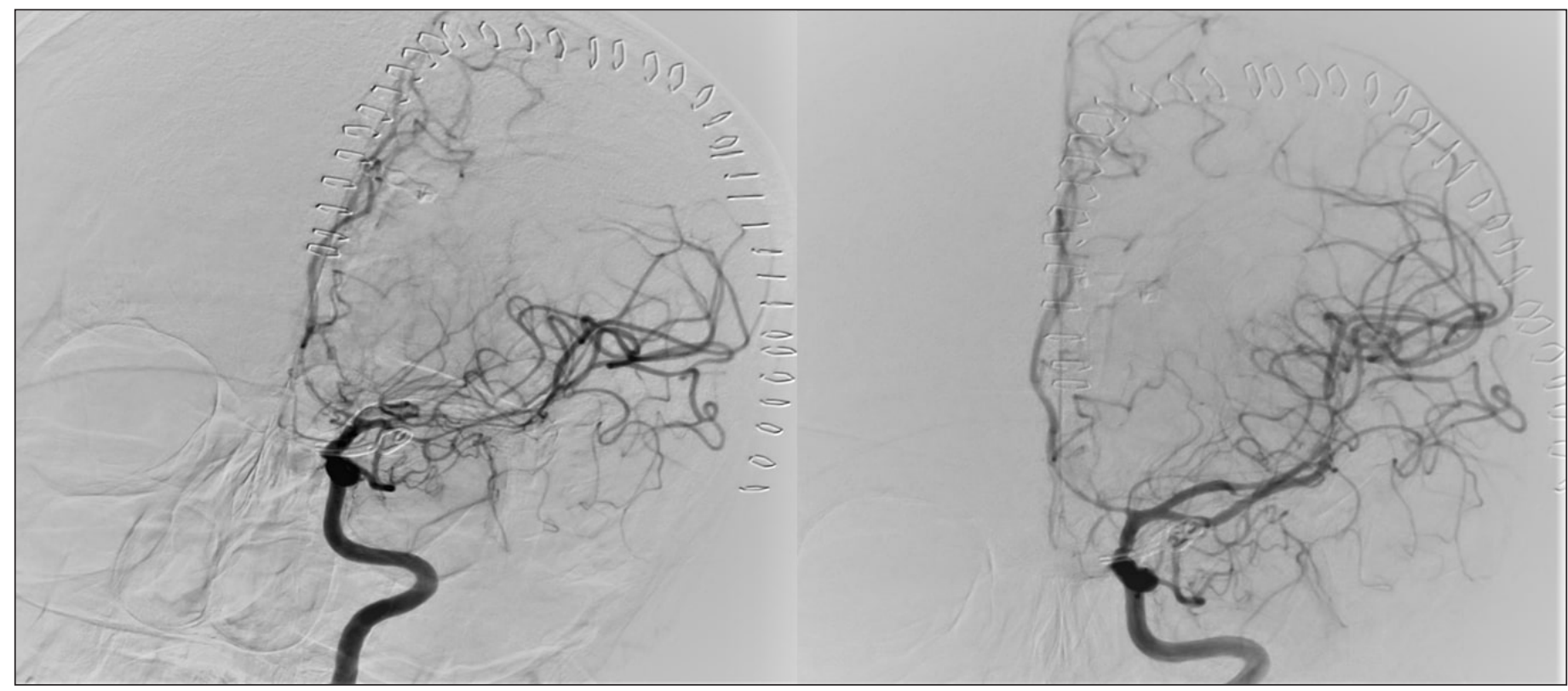

Figure 2. Vasospasm in a patient who was operated for left posterior communicating artery aneurysm and subsequent radiological improvement following intra-arterial nimodipine therapy. 


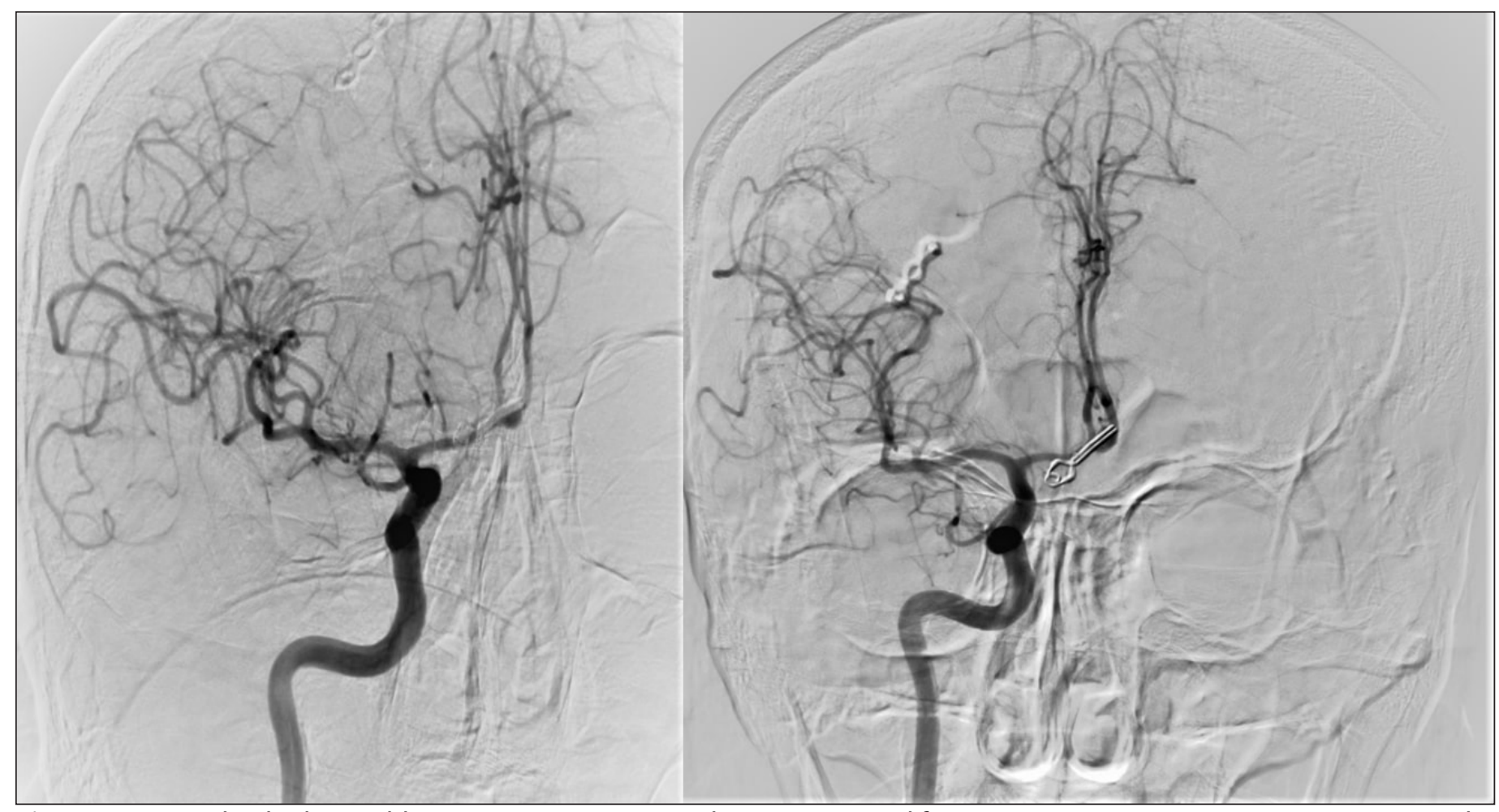

Figure 3. A not-clearly-discernible vasospasm in a patient that was operated for anterior communicating artery aneurysm. The patient enjoyed a significant clinical improvement after treatment, but there was not a significant radiological improvement.

\section{DISCUSSION}

In our study, the success rate of intra-arterial nimodipine therapy was $78.4 \%$. The clinical condition did not improve in $13.5 \%$ of cases and worsened in $8.1 \% .86 .4 \%$ of our patients were discharged with good outcomes (mRS score $0-1$ ).

Cerebral vasospasm is the main clinical finding that determines prognosis after subarachnoid hemorrhage. The vasoactive substances that are associated with vasospasm significantly affect the course of the disease due to their proinflammatory, vasoconstrictor, and various other undetermined effects. ${ }^{[13,14]}$ One of the major pathophysiological mechanisms involved in the development of cerebral vasospasm is changes in the metabolism of nitric oxide (NO). NO is a vasodilator that is directly associated with smooth muscle relaxation. Studies have demonstrated that extravascular hemoglobin and catabolism products that result from subarachnoid hemorrhage disrupt NO signaling between the vascular endothelium and the underlying smooth muscle cells. Also, even though the narrowing of major blood vessels plays an important role in delayed ischemic injury, recent studies suggest that alternative mechanisms such as early brain damage, loss of autoregulation of cerebral microcirculation, and microthrombosis also play a role in the pathogenesis of cerebral vasospasm. ${ }^{[15-18]}$

Many interventional or medical treatment options have been proposed for the treatment of cerebral vasospasm. However, these methods have limited feasibility due to various reasons including the difficulty of application, lack of cost-effectiveness, and the high rates of treatment failure or adverse events. Intra-arterial calcium channel blockers are commonly used since they are partially outside of the abovementioned limitations. Numerous experimental studies have demonstrated that different vessels in the body contain various types of calcium channels and receptors on their endothelia. It is established that calcium channel receptors of the cerebral vascular endothelium are different than those of the peripheral blood vessels. Furthermore, multiple studies have shown that the intravenous and topical administration of calcium channel blockers, and especially nimodipine, dilate narrowed vessels.

Hanggi et al. ${ }^{[19]}$ administered intra-arterial nimodipine to 26 patients who developed cerebral vasospasm after subarachnoid hemorrhage. They reported that most of these patients showed clinical and angiographic improvement and increased cerebral perfusion. Some authors argue that intraarterial nimodipine is a more effective treatment compared to intra-arterial papaverine. ${ }^{[19]}$ In a different study, Hanggi et al. ${ }^{[19]}$ applied intra-ventricular nimodipine bolus to 8 patients with cerebral vasospasm, followed by continuous lumbar intrathecal nimodipine infusion. 3 patients showed complete clinical improvement, whereas there was no clinical improvement in 4 cases. ${ }^{[20]}$ In their study, Biondi et al. $^{\text {[12] }}$ reported that $76 \%$ of the patients treated with intraarterial nimodipine clinically improved and $72 \%$ were in good condition at discharge (mRS score $0-1)$. In their study, Musahl 
et al. ${ }^{[21]}$ reported good outcomes for intra-arterial nimodipine therapy and no new ischemic lesions. The experimental study of Onal et al. ${ }^{[22]}$ indicated that selective intra-arterial nimodipine therapy was more effective than intravenous and intrathecal administration. Roda et al. ${ }^{[23]}$ found that the extent of cortical ischemia was reduced in subjects with focal cerebral ischemia that were administered an adequate dose of intra-arterial nimodipine. A case report by Böker et al. ${ }^{[24]}$ indicates that vasospasm angiographically resolved in all 3 patients that postangiographically received intra-arterial nimodipine therapy. We ascribe the differences in treatment outcomes to several factors. The most significant factor is that, even though this procedure is fundamentally a medical treatment, it is an invasive process. Therefore, the outcome will be significantly associated with the ability of the practitioner. Secondly, we believe the outcome is most likely associated with the dosage and duration of nimodipine therapy. Indeed, in the aforementioned studies, the dosage and duration of treatment and the practitioners that administered nimodipine are completely different from our study.

In our study, the clinical conditions of 3 patients worsened after intra-arterial nimodipine therapy. We were unable to conclusively determine whether this resulted from the nimodipine treatment or the present cerebral vasospasm. However, we believe it is very likely associated with cerebral vasospasm since we did not observe any complications associated with the treatment. In their 2019 study, Adami D. et al. ${ }^{[25]}$ investigated the use of balloon angioplasty and intraarterial nimodipine for the treatment of vasospasm. They concluded that angioplasty was associated with a higher risk of thromboembolic events and arterial dissection and that it should not be considered as a first choice even in patients with severe vasospasm but only as a last resort.

The primary limitation of our study is its retrospective nature. Other limitations include the small number of subjects and not having tried different doses or durations of nimodipine therapy in patients that did not respond to intra-arterial nimodipine treatment.

We conclude that intra-arterial nimodipine therapy is a costeffective, safe, and successful method for the treatment of cerebral vasospasm, a condition that directly affects morbidity and mortality after subarachnoid hemorrhage. Prospective studies are needed to determine standard doses and application times in order to establish the efficacy of intraarterial nimodipine therapy in treating cerebral vasospasm.

\section{ETHICAL DECLARATIONS}

Ethics Comittee Approval: The study was carried out with the permission of Adana City Training and Research Hospital Clinical Researches Ethics Committee (Permission granted 03.06.2020, Decision No. 903).

Informed Consent: Because the study was designed retrospectively, no written informed consent form was obtained from patients.
Status of Peer-review: Externally peer-reviewed.

Conflict of Interest Statement: The authors have no conflicts of interest to declare.

Financial Disclosure: The authors declared that this study has received no financial support.

Author Contributions: All of the authors declare that they have all participated in the design, execution, and analysis of the paper, and that they have approved the final version.

\section{REFERENCES}

1. San-Juan D, Zenteno MA, Trinidad D, et al. A pilot study of facial nerve stimulation on cerebral artery vasospasm in subarachnoid hemorrhage patients. IEEE J Transl Eng Health Med 2019;7:1800707.

2. Bahadir S, Narin F, Başar I, Hanalioğlu Ş, Bilginer B, Akalan N The effect of pentoxifylline on cerebral vasospasm following experimental subarachnoid hemorrhage. Int J Neurosci 2020;1-5. doi: 10.1080/00207454.2020.1760268.

3. Gross BA, Lai PMR, Frerichs KU, Du R. Treatment modality and vasospasm after aneurysmal subarachnoid hemorrhage. World neurosurg 2014;82(6):e725-e30.

4. Song JN, An JY, Hao GS, et al. Role of Akt signaling pathway in delayed cerebral vasospasm after subarachnoid hemorrhage in rats. Acta Neurochir (Wien) 2013;155(11):2063-70.

5. Ferguson S, Macdonald RL. Predictors of cerebral infarction in patients with aneurysmal subarachnoid hemorrhage. Neurosurgery 2007;60(4):658-67.

6. de Oliveira JG, Beck J, Ulrich C, Rathert J, Raabe A, Seifert V. Comparison between clipping and coiling on the incidence of cerebral vasospasm after aneurysmal subarachnoid hemorrhage: a systematic review and meta-analysis. Neurosurg rev 2007;30(1):22-31.

7. Macdonald RL, Kassell NF, Mayer S, et al. Clazosentan to overcome neurological ischemia and infarction occurring after subarachnoid hemorrhage (CONSCIOUS-1) randomized, double-blind, placebocontrolled phase 2 dose-finding trial. Stroke 2008;39(11):3015-21.

8. Kazda S, Towart R. Nimodipine: a new calcium antagonistic drug with a preferential cerebrovascular action. Acta Neurochir (Wien) 1982;63(14):259-65.

9. Towart R. The selective inhibition of serotonin-induced contractions of rabbit cerebral vascular smooth muscle by calcium-antagonistic dihydropyridines. An investigation of the mechanism of action of nimodipine. Circ Res 1981;48(5):650-7.

10. Kazda S, Hoffmeister F. Effect of some cerebral vasodilators on the postischemic impaired cerebral reperfusion in cats. In Naunyn-Schmıedebergs Archıves Of Pharmacology. 1979. Sprınger Verlag 175 Fifth Ave, New York, Ny 10010.

11. Vatter H, Güresir E, Berkefeld J, et al. Perfusion-diffusion mismatch in MRI to indicate endovascular treatment of cerebral vasospasm after subarachnoid haemorrhage. J Neurol Neurosurg Psychiatry 2011;82(8):876-83.

12. Biondi A, Ricciardi GK, Puybasset L, et al. Intra-arterial nimodipine for the treatment of symptomatic cerebral vasospasm after aneurysmal subarachnoid hemorrhage: preliminary results. AJNR Am J Neuroradiol 2004;25(6):1067-76.

13. Garzon-Muvdi T, Pradilla G., Ruzevick JJ, et al. A glutamate receptor antagonist, S-4-Carboxyphenylglycine (S-4-CPG), Inhibits vasospasm after subarachnoid hemorrhage in haptoglobin 2 to 2 mice. Neurosurgery, 2013;73(4):719-29.

14. Schebesch KM, Herbst A, Bele $S$, et al. Calcitonin-gene related peptide and cerebral vasospasm. J Clin Neurosci 2013;20(4):584-6.

15. Sehba FA, Schwartz AY, Chereshnev I, Bederson JB. Acute decrease in cerebral nitric oxide levels after subarachnoid hemorrhage. J Cereb Blood Flow Metab 2000;20(3):604-11. 
16. Clatterbuck RE, Gailloud P, Tierney T, Clatterbuck VM, Murphy KJ, Tamargo RJ. Controlled release of a nitric oxide donor for the prevention of delayed cerebral vasospasm following experimental subarachnoid hemorrhage in nonhuman primates. J Neurosurg 2005;103(4):745-51.

17. Pluta RM. Delayed cerebral vasospasm and nitric oxide: review, new hypothesis, and proposed treatment. Pharmacol Ther 2005;105(1):23-56.

18. Saber H, Desai A, Palla M, Mohamed W, Seraji-Bozorgzad N, Ibrahim M. Efficacy of cilostazol in prevention of delayed cerebral ischemia after aneurysmal subarachnoid hemorrhage: a meta-analysis. J Stroke Cerebrovasc Dis 2018;27(11):2979-85.

19. Hänggi D, Turowski B, Beseoglu K, Yong M, Steiger H. Intra-arterial nimodipine for severe cerebral vasospasm after aneurysmal subarachnoid hemorrhage: influence on clinical course and cerebral perfusion. AJNR Am J Neuroradiol 2008;29(6):1053-60.

20. Hänggi D, Beseoglu K, Turowski B, Steiger HJ. Feasibility and safety of intrathecal nimodipine on posthaemorrhagic cerebral vasospasm refractory to medical and endovascular therapy. Clin Neurol Neurosurg 2008;110(8):784-90.

21. Musahl C, Henkes H, Vajda Z, Coburger J, Hopf N. Continuous local intraarterial nimodipine administration in severe symptomatic vasospasm after subarachnoid hemorrhage. Neurosurgery 2011;68(6):1541-7.

22. Onal MB, Civelek E, Kircelli A, et al. Comparison of nimodipine delivery routes in cerebral vasospasm after subarachnoid hemorrhage: an experimental study in rabbits. Acta Neurochir Suppl 2011;110(Pt 2):23-8.

23. Roda JM, Carceller F, Díez-Tejedor E, Avendaño C. Reduction of infarct size by intra-arterial nimodipine administered at reperfusion in a rat model of partially reversible brain focal ischemia. Stroke 1995;26(10):1888-92.

24. Böker DK, Solymosi L, Wassmann H. Immediate postangiographic intraarterial treatment of cerebral vasospasm after subarachnoid hemorrhage with nimodipine: report on 3 cases. Neurochirurgia 1985;28(S 1):118-20.

25. Adami D, Berkefeld J, Platz J, et al. Complication rate of intraarterial treatment of severe cerebral vasospasm after subarachnoid hemorrhage with nimodipine and percutaneous transluminal balloon angioplasty: Worth the risk? J Neuroradiol 2019;46(1):15-24. 